\title{
EVALUASI KUAT TEKAN BETON RECYCLE AGREGAT DENGAN CAMPURAN AIR LAUT DAN PREDIKSI MODULUS ELASTISITASNYA
}

\author{
Lusman Sulaiman ${ }^{1)}$ \\ ${ }^{1)}$ Dosen Program Studi Teknik Sipil, Universitas Andi Djemma, Palopo \\ ${ }^{1)}$ lusman.sulaiman@ftunanda.ac.id
}

\begin{abstract}
Abstrak
Produksi beton dengan konsumsi air tawar yang cukup tinggi menjadi fokus utama oleh pemerintah dan insinyur akhir-akhir ini untuk mengatasi permasalahan yang terjadi. Ditambah, agregat normal (AN) yang semakin hari semakain berkurang jumlahnya dari sumber-sumber alamiahnya merupakan hal yang krusial untuk mencari alternatif pengganti. Oleh karena itu, penelitian ini memaparakan secara eksplisit sifat kuat tekan beton recycle agregat dengan air laut sebagai campuran dalam pembuatan beton sebagai material bangunan struktur dan prediksi modulus elastisitasnya. Pengujian eksperimen laboratorium dilakukan terhadap total tiga puluh spesimen uji berbentuk silinder $(15 \times 30 \mathrm{~cm})$ untuk mengevaluasi durabilitas beton dibawah pengaruh beban tekan dengan target sebesar $300 \mathrm{~kg} / \mathrm{cm}^{2}$ (29 MPa). Dua komposisi campuran yang berbeda disiapkan dimana campuran pertama adalah $100 \%$ air laut dan $100 \%$ agregat recycle dan kedua adalah campuran $100 \%$ air tawar dan $100 \%$ agregat recycle sebagai kontrol beton dengan faktor air semen sebesar 0.45. Kemudian spesimen uji diletakkan kedalam bak perendaman yang menggunakan air tawar dengan perbedaan waktu perawatan yaitu 3, 7, 14, 21, dan 28 hari. Hasil pengujian memperlihatkan bahwa kombinasi antara beton agregat recycle dengan campuran air laut (BAR-AL) memiliki kuat tekan awal tinggi pada umur 3 hari perawatan dan dicapai perbedaan kuat tekan sebesar $21 \%$ jika dibandingkan beton agregat recycle dengan campuran air tawar (BAR-AT) pada umur 28 hari. Oleh karena iu, diperlukan metode pendekan tertentu untuk meningkatkan kuat tekan BAR-AL agar setara bahkan lebih besar dari kuat tekan BAR-AT. Prediksi modulus elastisitas beton recycle dilakukan dengan menggunakan empat pendekatan matematis. Dari hasil analisis, persamaan empiris modulus elastisitas yang lebih mendekati real adalah dengan menggunakan pers.5 untuk BAR-AL dan persamaan matematis ACI318-14 untuk BAR-AT.
\end{abstract}

Kata Kunci: Kuat Tekan, Beton Agregat Recycle, Air Laut, Modulus Elastisitas.

\section{PENDAHULUAN}

Konsumsi jutaan meter kubik air tawar dan agregat normal (AN) sebagai campuran pembuatan beton tidak dapat dihindari sementara material alamiah tersebut semakin hari semakin terbatas jumlahnya. Oleh karena itu, diperlukan usaha alternatif pengganti atau subtitusi demi keberlangsungan (sustainable) pembangunan infrastruktur dan industri beton. Seperti diketahui bahwa air laut merupakan material yang menempati $80 \%$ permukaan bumi yang dapat ditemukan dengan mudah. Selain itu, material agregat recycle (AR) dari sisa penghancuran dan buangan (P\&B) konstruksi dan industri beton merupakan material yang cukup menjanjikan sebagai material konstruksi bangunan sebab telah banyak diteliti dan menjadi material konstruksi struktur bangunan yang cukup menjanjikan karena memiliki sifat-sifat yang serupa beton agregat normal (BAN) baik ditinjau dari sisi durabilitas maupun kekuatan (McNeil \& Kang 2013; Malešev, Radonjanin, \& Marinković 2010; El-Hawary \& AlOtaibib 2017).

Durabilitas dan kekuatan beton adalah hal yang paling penting dalam penentuan ketahanan terhadap berbagai kondisi lingkungan seperti lingkungan air laut. Kerusakan beton akibat kondisi lingkungan air laut yang agresif menjadi topik menarik untuk dikaji lebih mendalam akhir-akhir ini. Beberapa peneliti telah melakukan studi dengan menggunakan air laut bukan hanya sebagai campuran dalam pembuatan beton tetapi juga sebagai air perendaman (Alizadeh et al. 2008; Mbadike \& Elinwa 2011; Islam \& Islam 2012; Cwirzen, Sztermen, \& Habermehl-Cwirzen 2014). 
Oleh karena itu, hal ini menjadi objek dinamis untuk dikaji lebih mendalam sebab air laut yang mengandung konstituen utama seperti ion-ion klorida, magnesium, sodium, kalsium dan potassium dimana reaksi kimia air laut pada beton akan membentuk kristalisasi hingga membentuk cairan magnesium hidroxida $\left(\mathrm{Mg}(\mathrm{OH})_{2}\right)$ dan akhirnya memaksa terbentuknya gypsum yang menyebabkan terjadinya erosi beton (Wegian 2010; ACI 210R 1998).

Penelitian terbaru yang menggunakan air laut sebagai material campuran dan air tawar sebagai perendaman dalam memperoduksi beton normal memperlihatkan bahwa terjadi peningkatan kuat tekan dari umur 7 hingga 90 hari dan memiliki nilai berat maksimum di umur 28 hari (Abdel-Magid et al. 2016). Selain itu, menurut literatur (Osuji \& Nwankwo 2015; Akshat Dimri, Jay Kr. Varshney, V. K. Verma, Sandeep Gupta, \& G.B.Pant University of Agriculture and Technology, Pantnagar 2015; Lollini et al. 2016) penggunaan air laut sebagai campuran beton normal nampak tidak mereduksi kekuatan seperti kuat tekan, modulus elastisitas dan lainnya. Akan tetapi, yang perlu diperhatikan pada struktur beton yang terekspose pada kondisi lingkungan air laut baik yang terkena langsung atau tidak adalah korosi tulangan yang dapat dihindari dengan menggunakan besi stainless atau inhibitor.

Selanjutnya, kombinasi campuran air laut dan agregate recycle (AR) untuk produksi beton struktur masih sedikit dilakukan terutama kondisi lingkungan wilayah Indonesia. Oleh karena itu, perlu penelitian lebih jauh dengan memanfaatkan limbah hasil penghancuran dan buangan $(\mathrm{P} \& \mathrm{~B})$ konstruksi dan industri beton yang memiliki nilai ekonomis dan dapat mereduksi dampak lingkungan yang ditimbulkannya dan air laut yang jumlahnya tak terbatas sebagai pengganti air tawar dimana semakin hari semakin berkurang dari sumber-sumber alamiahnya. Berdasarkan penjelasan diatas, maka proyek penelitian ini bertujuan mengevaluasi kuat tekan beton agregat recycle dengan penggunaan air laut dalam campuraan pembuatan beton sebagai material baru untuk konstruksi bangunan struktur dan memprediksi perilaku modulus elastisitasnya.

\section{Signifikansi penelitian}

\subsection{Beton agregat recycle}

Beton agregat recycle (BAR) adalah beton yang diproduksi dengan menggunakan material agregat recycle. Material agregat recycle dapat diperoleh dari hasil proses P\&B konstruksi dan industri beton yang kebanyakan hanya dijadikan sebagai timbunan. Dengan pemanfaatan ini menjadi BAR, Beberapa Negara telah terfokus menggunakan material buangan ini menjadi beton baru yang memiliki keunggulan linier dengan kekuatan beton normal. Selain itu, Aplikasi BAR dalam dunia konstruksi beton dapat mereduksi dampak ekologi lingkungan dengan tidak mengexploitasi material agregat alam (Corbu et al. 2015).

Menurut Ho et al. (2013) dalam penelitian mereka mengenai penggunaan BAR sebagai beton struktural memaparkan bahwa di Singapura beberapa dekade lalu sudah menggunakan teknologi tinggi dalam memproduksi agregat recycle beton (ARB), namun masih sangat terbatas penggunaanya hanya pada bangunan nonstruktural, konstruksi perkerasan jalan dan timbunan. Oleh karena itu, mereka mencoba menganalisis material yang dianggap sampah ini menjadi material siap diterapkan sebagai konstruksi bangunan struktural. Hasil yang diperoleh cukup menjanjikan bahwa BAR dapat didesain untuk dapat bersaing dengan BAN dari sisi kuat tekan dan modulus elastisitas. Hal tersebut sangat dipengaruhi oleh sifat dan karakteristik fisik dan mekanik ARB (Malešev, Radonjanin, \& Bro 2014). 
Kabir, Al-Shayeb, \& Khan (2016) memperlihatkan bahwa ARB memiliki sifat berat jenis yang lebih rendah dari AN, yang biasanya sekitar 2.2-2.5 pada kondisi saturated surface dry (SSD). Penyerapan ARB memiliki nilai lebih tinggi dari AN, yang kemungkinan besar disebabkan oleh karena mortar yang melekat pada partikel ARB. Walaupun demikian hasil pengujian memperlihatkan bahwa kelayakan BAR digunakan sebagai beton struktural yang dilihat dari beberapa metode digunakan dengan nilai korelasi tinggi yaitu antara 0.84-0.99. Hal serupa juga diperlihatkan dari penelitian Malešev et al. (2010) bahwa dari ketiga kategori campuran yaitu BAN sebagai kontrol beton dan dua jenis BAR (50 dan 100\% pengganti ARB), BAR memiliki performa baik dan tidak ada perbedaan signifikan terhadap BAN dalam karakteristik kekuatan.

Durabilitas adalah salah satu parameter yang sering dipakai dalam penentuan kelayakan beton sebagai konstruksi struktur bangunan yang utamanya berada pada kondisi lingkungan pantai. Sifat resistensi BAR menjadi sangat penting terhadap penetrasi partikel ion klorida kedalam pori-pori atau retakan matriks beton $(\mathrm{Wu}, \mathrm{Diao}$, Ye, \& Zheng 2017), jika mencapai besi tulangan maka dapat menyebabkan korosi. Untuk menghindari hal tersebut, Lollini et al. (2016) merekomendasikan menggunakan stainless steel dan apabila air laut yang digunakan sebagai campuran dalam produksi beton, maka sangat direkomendasikan untuk meningkatkan selimut betonnya agar dapat mencapai target layanan struktur beton tersebut 50 hingga 100 tahun.

Umumnya, air laut mengandung 3 3.5\% ion klorida adalah partikel yang memiliki sifat degradasi misalnya karbonasi beton. Gao, Xia, \& Feng (2014) melakukan penelitian tentang karbonasi pada BAR dengan menggunakan dua jenis material buangan yaitu sisa blok jalan beton dan hasil pengujian spesimen beton di laboratorium sebagai agregat kasar dan halus serta kombinasi agregat normal. Hasil penelitian menyimpulkan bahwa kedalam karbonasi RAB menurun seiring penggantian agregat normal. Akan tetapi, berdasarkan penelitian Šefflová \& Pavlů (2016) tentang karbonasi pada agregat recycle halus yang diperoleh dari sisa $\mathrm{P} \& \mathrm{~B}$ konstruksi beton menyimpulkan bahwa layaknya penggunaan material buangan ini digunakan dalam pembuatan beton tetapi diperlukan kajian lebih lanjut.

\subsection{Sifat mekanik BAR}

\subsubsection{Kuat tekan}

Beton adalah material yang kuat terhadap beban tekan namun lemah terhadap beban tarik. Untuk mengevaluasi kekuatannya, pengujian beban tekan adalah umum digunakan dengan cara menggunakan mesin tekan (compression machine) dimana hal serupa dapat dilakukan pada BAR. Beberapa penelitian telah dilakukan untuk mengetahui kuat tekan BAR seperti Lalla \& Mwasha, (2014) menginvestigasi dan menganalisis kuat tekan 30 sampel beton silinder dengan waktu pengujian berbeda yaitu 3, 7, 14, 21 dan 28 hari. Dari hasil pengujian, kuat tekan pada umur 28 hari diperoleh kekuatan lebih dari kuat tekan rencana $30 \mathrm{MPa}$.

Evaluasi yang dilakukan oleh Kang \& Weibin (2018) terhadap pengaruh ukuran AR untuk pengujian kuat tekan. Tiga jenis ukuran partikel (A-5/16mm, B16/20, C-20/31.5) digunakan dalam produksi campuran BAR dengan rasio air semen sebesar 0.47 dan 0.53 serta variasi isi pengganti AN dalam beton. Hasilnya memperlihatkan bahwa semakin besar ukuran agregat maka semakin meningkat kekuatan tekan beton tersebut. Hal ini disebabkan oleh karena mortar lama lebih sedikit pada agregat ukuran besar dibanding agregat ukuran kecil. Hubungan antara 
beton normal dan beton recycle dalam hal kuat tekan vs mortar sangat spesifik dilakukan oleh Akbarnezhad, Ong, Tam, \& Zhang (2013). Namun, pada dasarnya mereka menyimpulkan bahwa sifat-sifat dan kekuatan beton tidak signifikan berpengaruh terhadap kuat tekan BAR akibat meningkatnya mortar lama pada agregat.

\subsubsection{Prediksi modulus elastisitas}

Parameter dasar yang penting dalam menganalisis pengaruh dan perilaku material terhadap perubahan sebuah struktur akibat beban-beban luar adalah modulus elastisitas. Modulus elastisitas beton Ec memiliki peran dalam pembangunan struktur bangunan baru dan kondisi elemen struktur yang telah ada (seperti, defleksi, puntir dan getaran). Peningkatan modulus elastisitas beton akan terlihat dari umur 7 hari hingga 28 hari. Dalam periode 28 hingga 90 hari tidak akan terjadi perubahan begitu signifikan (Kř́žžová \& Hela 2016).

Prediksi modulus elastisitas beton dimungkinkan dapat diperoleh secara tidak langsung dengan menggunakan hasil pengujian kuat tekan f'c. Sejumlah persamaan empiris dapat digunakan untuk menilai modulus elastisitas beton normal. The American Concrete Institute ACI-318 (2014) tentang code persyaratan bangunan untuk struktur beton mengisinkan besarnya modulus elastisitas dengan rentang berat jenis Wc $\left(1442 \mathrm{~kg} / \mathrm{m}^{3} \sim 2563 \mathrm{~kg} / \mathrm{m}^{3}\right)$ untuk nilia f'c dibawah $38 \mathrm{MPa}$ dengan menggunakan pers. 1. Untuk berat jenis beton normal $\left(2400 \mathrm{~kg} / \mathrm{m}^{3}\right)$, Modulus elastititas $(\mathrm{MPa})$ dapat dihitung dengan menggunakan pers. 2.

$$
\begin{aligned}
& E_{A C I 318}=W_{c}^{1.5} 0.043 \sqrt{f_{c}^{\prime}} \\
& E_{A C I 318}=4700 \sqrt{f_{c}^{\prime}}
\end{aligned}
$$

The Comit'e-Euro-International du B'eton dan the F'ed'eration Internationale de la Pr'econtrainte (CEB-FIP) Model code dan Eurocode 2 menganjurkan menggunakan persamaan empiris untuk mendapatkan nilai Ec (MPa) dari hasil pengujian kuat kan f'c seperti pers. 3 berikut:

$$
E_{C E B-F I P}=22000\left(\frac{f_{c}^{\prime}}{10}\right)^{0.3}
$$

Lebih lanjut, Pendekatan dalam memprediksi modulus elastisitas untuk beton recycle, literatur (Wardeh, Ghorbel, \& Gomart 2015) memperlihatkan pers. 4 lebih sesuai digunakan dibanding pers. 3 .

$$
E_{26}=17553\left(\frac{f_{c}^{\prime}}{10}\right)^{0.42}
$$

Selain itu Yue, Tan, \& Guo (2013) menggunakan pers. 5 untuk memprediksi modulus elastisitas beton agregat recycle dibawah pengaruh korosi air laut dengan persentase pengganti agregat normal dengan agregat recycle sebesar 0\%, 30\%,dan $60 \%$.

$$
E_{27}=5.639 \sqrt{f_{c}^{\prime}-4.952}
$$

\section{METODE PENELITIAN}

\subsection{Material dan proporsi campuran}

Komposisi material untuk campuran yang digunakan dalam pembuatan beton yaitu terdiri dari semen type I, pasir sungai, agregat recycle kasar, air laut dan air tawar. Ordinary portland cement (OPC) digunakan dalam campuran pembuatan beton yang komposisinya serupa dengan semen type I-ASTM. Pasir sungai sebagai agregat halus yang memiliki gradasi $0-2 \mathrm{~mm}$ dan agregat recycle yang memiliki gradasi partikel sebesar 4-20 $\mathrm{mm}$, disiapkan. Agregat recycle diperoleh dengan menghancurkan sisa-sisa sampel beton hasil pengujian kuat tekan di laboratorium dari berbagai proyek lokal. Kemudian pemisahan antara mortar dan agregat kasarnya 
hingga dilakukan penyaringan dan penyortiran untuk mendapatkan ukuran yang diinginkan. Hasil pengujian agregat ini dapat dilihat pada tabel 1. Selanjutnya, air yang dipakai adalah air tawar sebagai pencampur dan perendaman spesimen dan air laut degan tingkat kadar garam 3\% sebagai campuran dalam pembuatan beton recycle.

Tabel 1. Karakteristik Fisik Dan Mekanik Agregat

\begin{tabular}{|l|c|c|}
\hline $\begin{array}{c}\text { Karakteristik fisik dan } \\
\text { mekanik agregat }\end{array}$ & Agregat recycle & Pasir sungai \\
\hline Berat jenis spesifik (kering oven) & 2.34 & 2.60 \\
\hline Berat jenis spesifik (SSD) & 2.35 & 2.66 \\
\hline Berat jenis spesifik (apparent) & 2.64 & 2.78 \\
\hline Persen penyerapan (\%) & 4.11 & 1.63 \\
\hline Persen keausan (\%) & 24.67 & - \\
\hline Modulus kekasaran (\%) & 3.71 & 2.86 \\
\hline
\end{tabular}

\subsection{Standar spesimen dan perawatan}

Proses desain campuran dalam pembuatan benda uji yang akan diadopsi pada penelitian ini adalah metode BRE/DOE system (Day 1999). Material yang digunakan dalam perencanaan desain campuran pembuatan beton recycled agregat (BAR) berdasarkan sifat-sifat hasil pengujian yang ditargetkan dengan rencana kuat tekan sebesar $29 \mathrm{MPa}$ (benda uji silinder ukuran 150x300 mm), faktor air semen rencana sebesar 0.45 dan slump beton segar sebesar $120 \mathrm{~mm}$. Dua kategori spesimen beton disiapkan dengan menggunakan $100 \%$ agregat recycle kasar yaitu pertama: semen, pasir, agregat recycle kasar dan air laut (BAR-AL), kedua: semen, pasir, agregat recycle kasar dan air tawar (BAR-AT) sebagai kontrol dan pembanding. Tabel 2 memperlihatkan proporsi campuran utnuk setiap $1 \mathrm{~m}^{3}$. Material campuran dalam pembuatan beton yang telah terbentuk menghasilkan beton segar dan siap untuk dicetak pada mold silinder. Kemudian beton segar tersebut dimasukkan sebanyak tiga tahap hingga terisi dan memadat pada mold silinder. Tiap tahap pengisian beton segar ditusuk-tusuk sebanyak 25 kali tusukan dengan menggunakan tongkat penusuk besi $\phi 12 \mathrm{~mm}$. Selanjutnya total 30 benda uji silinder beton segar dibiarkan selama 24 jam hingga campuran beton mengeras dan siap dilakukan perawatan (curing).

Tata cara pembuatan dan perawatan benda uji beton di laboratorium berdasarkan SNI 2439:2011. Periode perawatan spesimen adalah berbeda yaitu 3, 7, 14, 21, dan 28 hari dengan menggunakan air tawar sebagai media perawatan. Ketika perendaman telah mencapai periode pengujian, spesimen kemudian diangkat dan dianginkan untuk menghilangkan air serapan pada beton dalam beberapa saat. Hal ini bertujuan untuk memastikan bahwa pada saat pengujian beban tekan maka material tidak terpengaruh oleh air yang terperangkap dalam pori-pori beton. Adapun detail spesimen untuk pengujian kuat tekan dapat dilihat pada tabel 3.

Tabel 2. Proporsi Desain Campuran Beton Segar

\begin{tabular}{|c|c|c|c|c|}
\hline $\begin{array}{c}\text { Jenis } \\
\text { cetakan }\end{array}$ & $\begin{array}{c}\text { Semen } \\
\left(\mathbf{k g} / \mathbf{m}^{3}\right)\end{array}$ & $\begin{array}{c}\text { Pasir } \\
\left(\mathbf{k g} / \mathbf{m}^{3}\right)\end{array}$ & $\begin{array}{c}\text { Agregat } \\
\text { recycle kasar } \\
\left(\mathbf{k g} / \mathbf{m}^{\mathbf{3}}\right)\end{array}$ & $\begin{array}{c}\text { Air } \\
\left(\mathbf{k g} / \mathbf{m}^{3}\right)\end{array}$ \\
\hline Silinder & 411.11 & 681.11 & 1022.77 & 185 \\
\hline
\end{tabular}


Tabel 3. Detail Program Eksperimen

\begin{tabular}{|c|c|c|c|c|c|c|}
\hline $\begin{array}{l}\text { Kategori } \\
\text { spesimen }\end{array}$ & Material penyusun & $\begin{array}{c}\text { Kuat } \\
\text { tekan } \\
\text { rencana } \\
\text { (Mpa) } \\
\end{array}$ & Rasio w/c & $\begin{array}{c}\text { Spesimen } \\
\text { (buah) }\end{array}$ & $\begin{array}{c}\text { Waktu } \\
\text { perendam } \\
\text { an (hari) }\end{array}$ & $\begin{array}{c}\text { Media } \\
\text { perendaman }\end{array}$ \\
\hline \multirow{5}{*}{ BAR-AT } & Semen type I & \multirow{5}{*}{25} & \multirow{5}{*}{0.45} & 3 & 3 & \multirow{10}{*}{ Air tawar } \\
\hline & Pasir sungai & & & 3 & 7 & \\
\hline & Agregat recycle kasar & & & 3 & 14 & \\
\hline & \multirow{2}{*}{ Air tawar } & & & 3 & 21 & \\
\hline & & & & 3 & 28 & \\
\hline \multirow{5}{*}{ BAR-AL } & Semen type I & \multirow{5}{*}{25} & \multirow{5}{*}{0.45} & 3 & 3 & \\
\hline & Pasir sungai & & & 3 & 7 & \\
\hline & Agregat recycle kasar & & & 3 & 14 & \\
\hline & \multirow{2}{*}{ Air laut } & & & 3 & 21 & \\
\hline & & & & 3 & 28 & \\
\hline
\end{tabular}

\subsection{Rancangan pengujian}

Pengujian kuat tekan (f'c) benda uji silinder beton dilakukan dengan menggunakan alat compression test atau alat uji kuat tekan dengan kapasitas alat yang akan digunakan pada penelitian ini dapat mencapai beban tekan hingga $50 \mathrm{MPa}$ dengan kecepatan secara berkesinambungan rata-rata sebesar 0.14 sampai $0.34 \mathrm{MPa}$ /detik. Keseluruhan prosedur pengujian kuat tekan benda uji silinder mengacu pada SNI 1947:2011 tentang cara penguji kuat tekan beton dengan benda uji silinder. Hasil pengujian kuat tekan kemudian digunakan dalam memprediksi modulus elastisitas beton dengan menggunakan empat persamaan matematis yang berbeda.

\section{HASIL DAN PEMBAHASAN}

\subsection{Kuat Tekan}

Pengujian kuat tekan menggunakan air laut dalam campuran pembuatan beton dengan menggunakaan RA telah dilakukan. Metode pendekatan eksperimen laboratorium menjadi dasar untuk menentukan kekuatan beton dari $100 \%$ campuran AR dan air laut. Gambar 1 memperlihatkan hasil pengujian kuat tekan rata-rata spesimen silinder dengan umur perawatan 3, 7, 14, 21, dan 28 hari.

Kekuatan tekan BAR dengan campuran air laut (BAR-AL) pada umur perawatan 3 hari memiliki kuat tekan lebih tinggi dibandingkan dengan BAR campuran air tawar (BAR-AT) yaitu sekitar 2\%. Namun, pada umur 7 hari kekuatan tekan BAR-AL mulai mengalami penurunan kekuatan sebaliknya BAR-AT terlihat mengalami peningkatan kekuatan tekan dengan perbedaan keduanya sebesar kurang dari $1 \mathrm{MPa}(2 \%)$. Selanjutnya, BAR-AL hanya sedikit mengalami peningkatan kuat tekan dari 20.27 $\mathrm{MPa}$ di umur 7 hari menjadi $20.65 \mathrm{MPa}$ di umur 14 hari pengujian sementara kuat tekan BAR-AT meningkat cukup signifikan dari $20.65 \mathrm{MPa}$ (7 hari) menjadi 27.72 $\mathrm{MPa}$ (14 hari).

Kemudian, pengujian di umur 21 dan 28 hari setelah mengalami perawatan air tawar, kuat tekan baik campuran BAR-AL maupun BAR-AT terus terjadi peningkatan secara bersamaan, akan tetapi kedua kategori campuran tersebut memiliki perbedaan kuat tekan yang cukup besar yaitu 8.77 MPa umur 21 hari dan 6.69 MPa umur 28 hari. Hal tersebut adalah tidak terlepas dari pengaruh campuran air laut yang memiliki sifat 
kuat tekan awal tinggi pada umur 3 hari dan sebab adanya pengaruh mortar lama yang masih melekat pada agregat kasar sehingga kuat tekan campuran BAR-AL hanya mengalami peningkatan kecil hingga umur 28 hari.

Seperti pada gambar 2 terlihat hubungan antara BAR-AL dan BAR-AT terhadap kuat tekan masing-masing yang memiliki korelasi yang cukup besar $R^{2}=0.9122$. Hubungan linier kedua kategori campuran (BAR-AL dan BAR-AT) dari hari ke hari hingga umur 28 hari terus terjadi peningkatan kuat tekan walaupun target kuat tekan $29 \mathrm{MPa}$ belum tercapai yaitu sebesar 24.70 MPa untuk campuran BAR-AL, sementara campuran BAR-AT telah melampaui target kuat tekan yaitu sebesar $31.39 \mathrm{MPa}$ yang terpaut sekitar $21 \%$ dari kuat tekan campuran BAR-AL.Hal ini kuat tekan BAR-AT tidak dipengaruhi sama sekali oleh air pencampuran akan tetapi mortar lama yang masih melekat pada ARK. Walaupun demikian baik BAR-AL dan BAR-AT masih layak digunakan sebagai material konstruksi bangunan struktural.

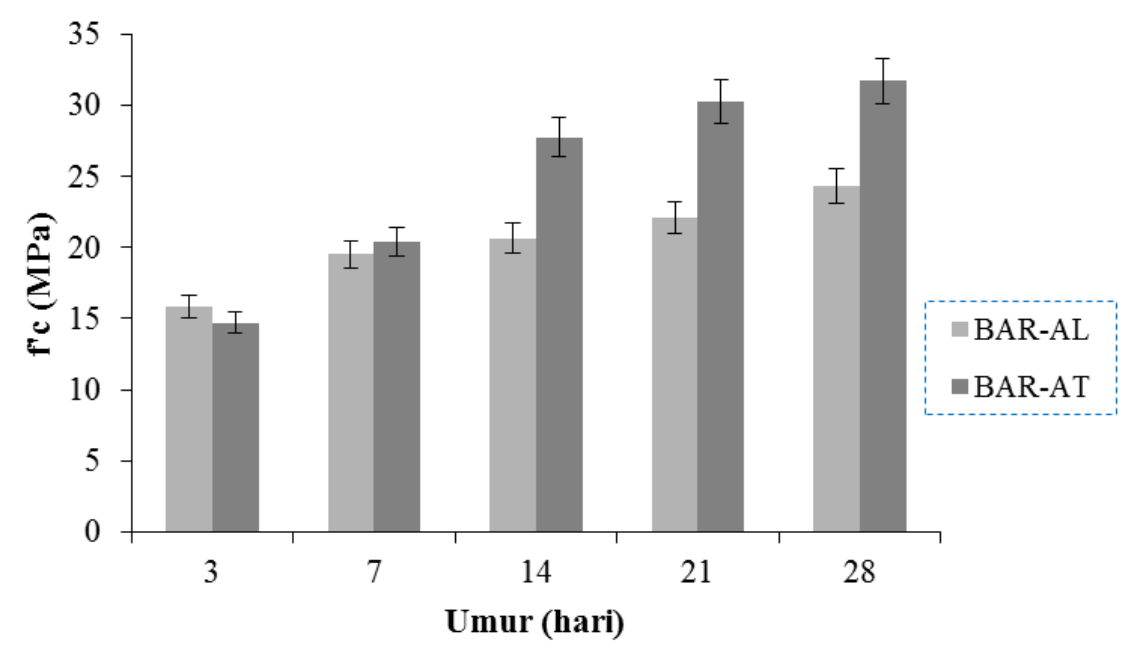

Gambar 1. Kuat Tekan BAR-AL dan BAR-AT

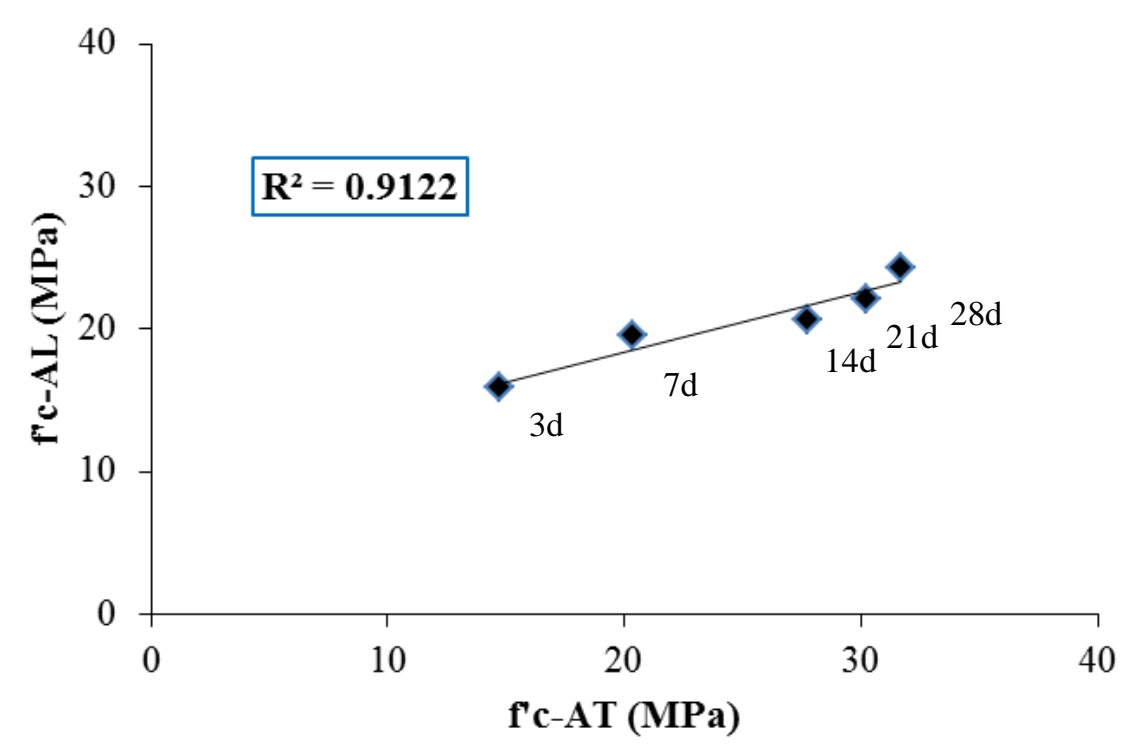

Gambar 2. Korelasi Antara BAR-AL dan BAR-AT 


\subsection{Hubungan Antara Modulus Elastisitas dan Umur Perawatan}

Prediksi modulus elastisitas BAR-AL dan BAR-AT dapat dilihat pada gambar 3 dan 4 berturut-turut. Trend peningkatan terlihat jelas dari umur 3 hingga maksimum di umur 28 hari. Modulus elastisitas beton umur 3, 7, 14, 21, dan 28 hari terlihat memiliki nilai minimum yaitu dengan menggunakan persamaan matematis pada literatur (Yue et al. 2013) atau pers. 5. Di sisi lain, Nilai maksimum modulus elastisitas BAR-AL dengan menggunakan pers. 3 (CEB-FIB) terlihat lebih tinggi dibandingkan ketiga persamaan yang ada dimana nilai interval maksimum dan minimum (pers. 3 dan pers. 5) cukup jauh berbeda rata-rata $10 \mathrm{GPa}$. Selain itu, Pers. 4 berada diantara kedua persamaan matematis tersebut. Sedangkan penggunakan pers. 2 (ACI318-14) terlihat sangat dekat dengan nilai Ec untuk pers. 5 yang terpaut sekitar rata-rata $2 \mathrm{GPa}$.

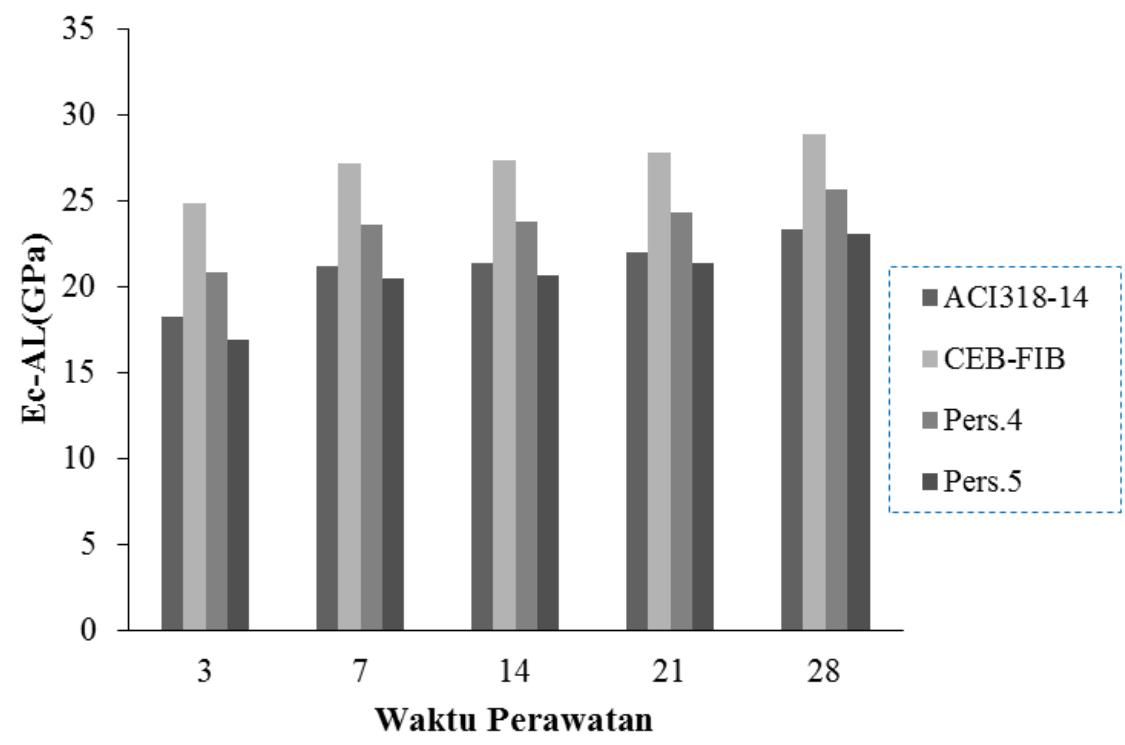

Gambar 3. Hubungan Modulus Elastisitas dan Waktu Perawatan BAR-AL

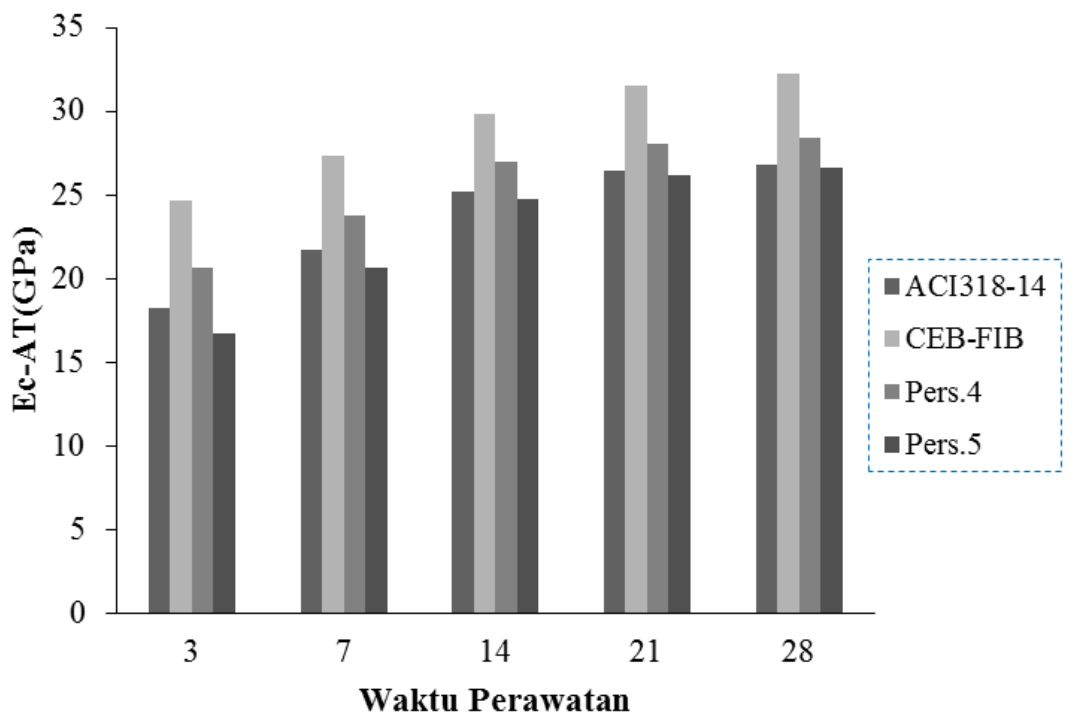

Gambar 4. Hubungan Modulus Elastisitas dan Waktu Perawatan BAR-AT 


\subsection{Hubungan Antara Modulus Elastisitas dan Kuat Tekan}

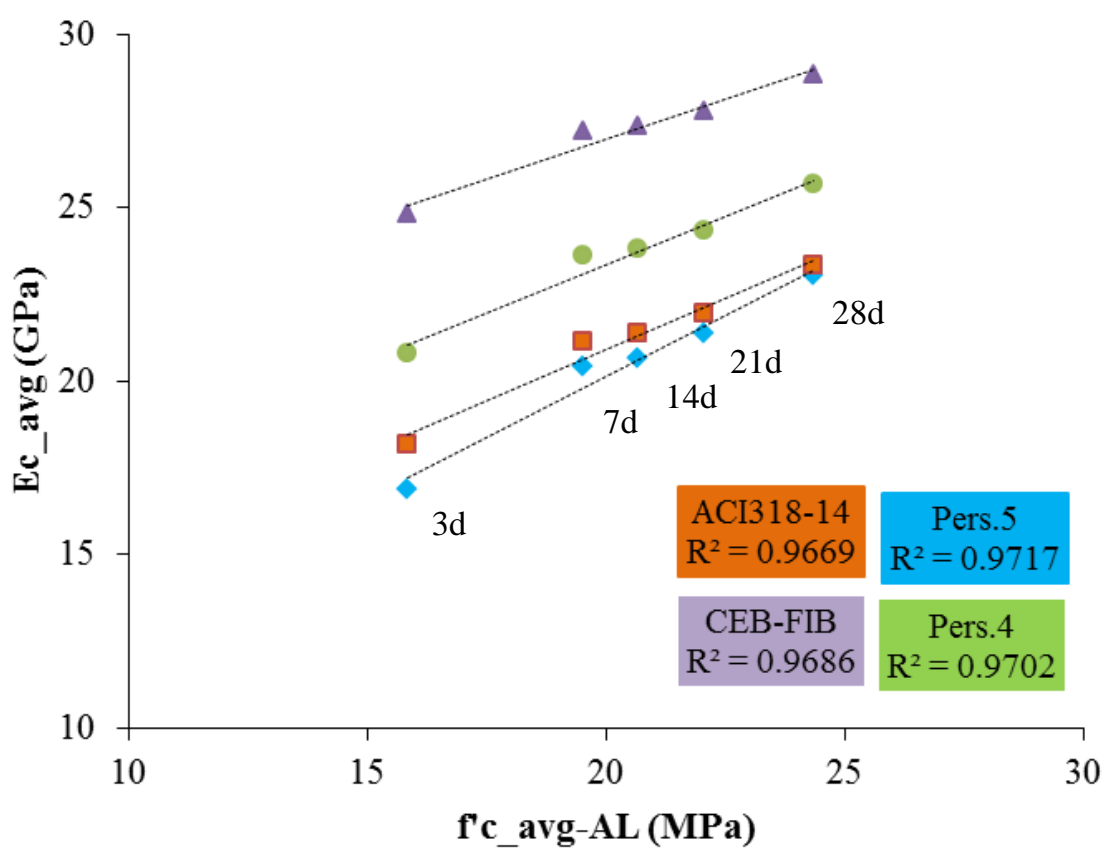

Gambar 5. Hubungan Antara Kuat Tekan dan Modulus Elastisitas BAR-AL

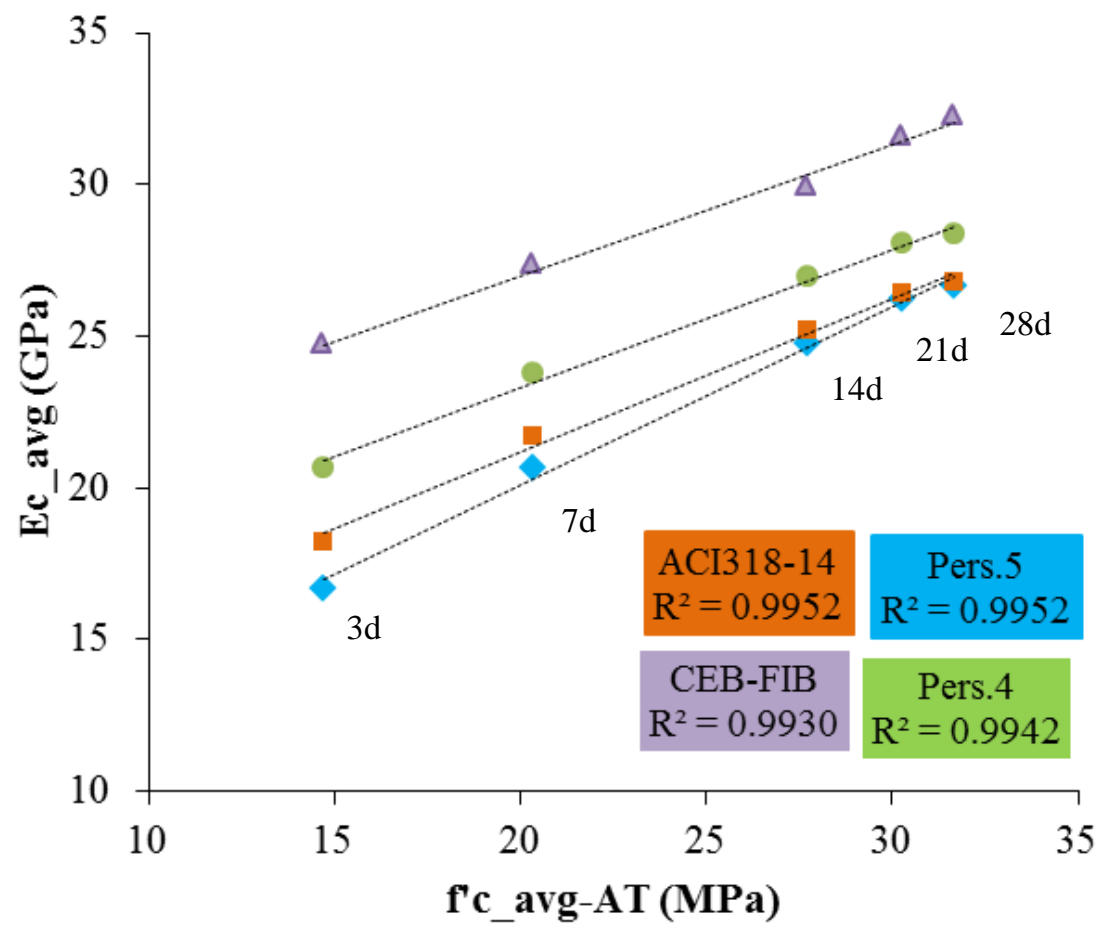

\section{Gambar 6. Hubungan Antara Kuat Tekan dan Modulus Elastisitas BAR-AT}

Gambar 5 dan 6 memperlihatkan dengan jelas korelasi antara kuat tekan dan modulus elastisitas BAR-AL dan BAR-AT. Gambar 5 menegaskan bahwa keempat persamaan yang diuraikan sebelumnya, maka prediksi modulus elastisitas dengan nilai $\mathrm{R}^{2}$ dari yang terbesar hingga terkecil yaitu Pers.5, Pers.4, ACI318, dan CEB-FIB dengan $\mathrm{R}^{2}=0.9717, \mathrm{R}^{2}=0.9702, \mathrm{R}^{2}=0.9669$, dan $\mathrm{R}^{2}=0.9686$ berturut-turut. Sedangkan, 
Gambar 6 memperlihatkan hal yang berbeda dimana nilai korelasi dari yang terbesar hingga terkecil yaitu Pers.5, ACI318, Pers.4, dan CIB-FIB dengan dengan $\mathrm{R}^{2}=0.9952$, $\mathrm{R}^{2}=0.9952, \mathrm{R}^{2}=0.9942$, dan $\mathrm{R}^{2}=0.9930$ berturut-turut. . Hal ini memperlihatkan bahwa penilaian terhadap keempat persamaan matematis (pers. 2 5) untuk memprediksi modulus elastisitas beton recycle dengan campuran air laut dapat menggunkan Pers. 5 dan air tawar dapat menggunakan persamaan matematis ACI31814 (pers. 2).

Lebih detail dapat diperlihatkan pada gambar 7, hubungan modulus elastisitas antara dua parameter BAR-AL dan BAR-AT adalah linier dengan nilai $\mathrm{R}^{2}$ tiap-tiap persamaan yang digunakan bervariasi. Persamaan $2,3,4$ dan 5 menunjukkan nilai $\mathrm{R}^{2}$ $=0.8553, \mathrm{R}^{2}=0.8590, \mathrm{R}^{2}=0.8560$ dan $\mathrm{R}^{2}=0.8532$ berturut-turut. Dari nilai-nilai tersebut memperlihatkan bahwa korelasi yang ditunjukkan pada gambar 3 dan 4 memiliki kedekatan cukup tinggi.

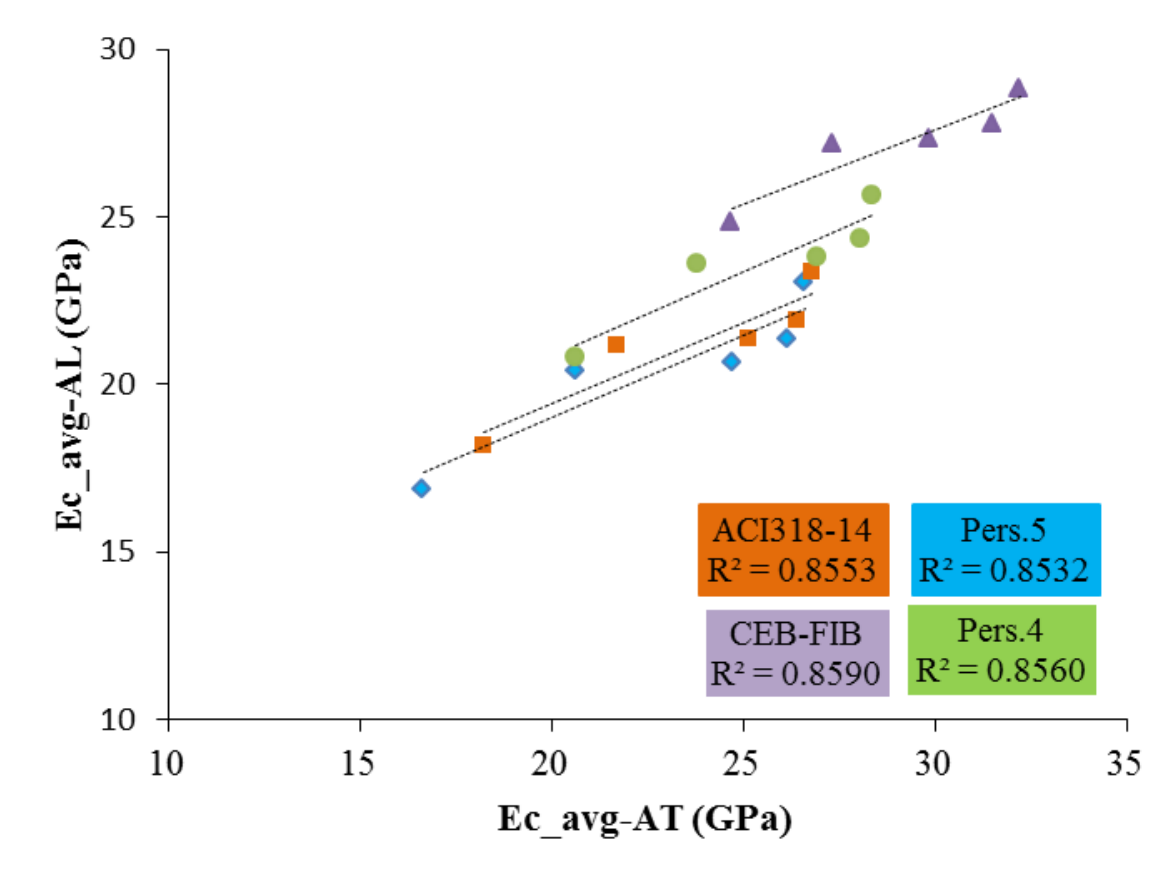

Gambar 7. Korelasi Modulus Elastisitas BAR-AL dan BAR-AT.

\section{KESIMPULAN}

Serangkaian studi eksperimen telah dilakukan untuk mengevaluasi kuat tekan BAR spesimen silinder $(150 \times 300 \mathrm{~mm})$ dan memprediksi modulus elastisitasnya dengan menghubungakan antara kuat tekan dan modulus elastisitas kedua kategori campuran BAR-AL dan BAR-AT. Dari pengujian dan analisis tersebut, penelitian ini dapat disimpulkan bahwa:

1. Kuat tekan beton BAR-AL lebih rendah $21 \%$ dibandigkan BAR-AT dengan nilai faktor air semen sebesar 0.45 yang diyakini disebabkan oleh karena mortar lama yang melekat pada ARK dan campuran air laut pada beton.

2. BAR-AL memiliki kuat tekan awal tinggi umur 3 hari dan akan mengalami penurunan kekuatan tekan maksimum di umur 28 hari dibandingkan BAR-AT. Sehingga diperlukan pendekatan tertentu untuk meningkatkan kuat tekannya hingga mencapai target $29 \mathrm{MPa}$. 
3. Kuat tekan BAR-AT dari umur 3 hingga 28 hari terus mengalami peningkatan hingga melampaui target rencanana dengan nilai sebesar rata-rata $31.39 \mathrm{MPa}$.

4. Dari hasil pengujian kuat tekan, prediksi modulus elastisitas untuk kategori kategori campuran BAR-AL dapat menggunakan pers.5 dan BAR-AT) dapat diprediksi dengan menggunakan pers. 2 (ACI318-14).

\section{DAFTAR PUSTAKA}

Abdel-Magid, T. I., Osman, O. M., Ibrahim, O. H., Mohammed, R. T., Hassan, S. O., \& Bakkab, A. A. H. (2016). Influence of Seawater in Strengths of Concrete Mix Design when Used in Mixing and Curing. Key Engineering Materials, 711, 382389. https://doi.org/10.4028/www.scientific.net/KEM.711.382

ACI 210R-93. (1998). Erosion of Concrete in Hydraulic Structures.

ACI-318-14. (2014). Building code requirements for structural concrete and commentary.

Akbarnezhad, A., Ong, K. C. G., Tam, C. T., \& Zhang, M. H. (2013). Effects of the Parent Concrete Properties and Crushing Procedure on the Properties of Coarse Recycled Concrete Aggregates. Journal of Materials in Civil Engineering, 25(12), 1795-1802. https://doi.org/10.1061/(ASCE)MT.1943-5533.0000789

Akshat Dimri, Jay Kr. Varshney, V. K. Verma, Sandeep Gupta, \& G.B.Pant University of Agriculture and Technology, Pantnagar. (2015). A Review on Strength of Concrete in Seawater. International Journal of Engineering Research And, V4(03). https://doi.org/10.17577/IJERTV4IS030890.

Alizadeh, R., Ghods, P., Chini, M., Hoseini, M., Ghalibafian, M., \& Shekarchi, M. (2008). Effect of Curing Conditions on the Service Life Design of RC Structures in the Persian Gulf Region. Journal of Materials in Civil Engineering, 20(1), 28. https://doi.org/10.1061/(ASCE)0899-1561(2008)20:1(2).

Corbu, O., Puskás, A., Sandu, A. V., Ioani, A. M., Hussin, K., \& Sandu, I. G. (2015). New Concrete with Recycled Aggregates from Leftover Concrete. Applied Mechanics and Materials, 754-755, 389-394. https://doi.org/10.4028/www.scientific.net/AMM.754-755.389.

Cwirzen, A., Sztermen, P., \& Habermehl-Cwirzen, K. (2014). Effect of Baltic Seawater and Binder Type on Frost Durability of Concrete. Journal of Materials in Civil Engineering, 26(2), 283-287. https://doi.org/10.1061/(ASCE)MT.19435533.0000803.

Day, K. W. (1999). Concrete Mix Design, Quality Control and Specification, Second Edition, 327.

El-Hawary, M. M., \& Al-Otaibib, S. F. (2017). On the Durability of Recycled Aggregates Concrete, 6(1), 4.

Gao, Y. R., Xia, Q., \& Feng, J. C. (2014). Research on Carbonation of Recycled Aggregate Concrete Using Different Recycled Concrete Aggregates. Applied Mechanics and Materials, 665, 155-158. https://doi.org/10.4028/www.scientific.net/AMM.665.155.

Ho, N. Y., Lee, Y. P. K., Lim, W. F., Zayed, T., Chew, K. C., Low, G. L., \& Ting, S. K. (2013). Efficient Utilization of Recycled Concrete Aggregate in Structural Concrete. Journal of Materials in Civil Engineering, 25(3), 318-327. https://doi.org/10.1061/(ASCE)MT.1943-5533.0000587.

Islam, M., \& Islam, S. (2012). Suitability of sea water on curing and compressive strength of structural concrete. Journal of Civil Engineering, 9. 
Kabir, S., Al-Shayeb, A., \& Khan, I. M. (2016). Recycled Construction Debris as Concrete Aggregate for Sustainable Construction Materials. Procedia Engineering, 145, 1518-1525. https://doi.org/10.1016/j.proeng.2016.04.191.

Kang, M., \& Weibin, L. (2018). Effect of the Aggregate Size on Strength Properties of Recycled Aggregate Concrete. Advances in Materials Science and Engineering, 2018, 1-8. https://doi.org/10.1155/2018/2428576.

Krrižová, K., \& Hela, R. (2016). Evaluation of the Modulus of Elasticity of Different Types of Concrete Compared with Eurocode 2. Key Engineering Materials, 677, 181-185. https://doi.org/10.4028/www.scientific.net/KEM.677.181.

Lalla, J. R. F., \& Mwasha, A. (2014). Investigating the Compressive Strengths of Guanapo Recycled Aggregate Concrete as Compared to that of its Waste Material, The West Indian Journal of Engineering, 32(6), 12-19.

Lollini, F., Carsana, M., Gastaldi, M., Redaelli, E., Bertolini, L., \& Naani, A. (2016). Preliminary Assessment of Durability of Sustainable RC Structures with MixedIn Seawater and Stainless Steel Reinforcement. Key Engineering Materials, 711, 52-59. https://doi.org/10.4028/www.scientific.net/KEM.711.52.

Malešev, M., Radonjanin, V., \& Bro, G. (2014). PROPERTIES OF RECYCLED AGGREGATE CONCRETE. Contemporary Materials, 11.

Malešev, M., Radonjanin, V., \& Marinković, S. (2010). Recycled Concrete as Aggregate for Structural Concrete Production. Sustainability, 2(5), 1204-1225. https://doi.org/10.3390/su2051204.

Mbadike, E. M., \& Elinwa, A. U. (2011). EFFECT OF SALT WATER IN THE PRODUCTION OF CONCRETE. Nigerian Journal of Technology, 30(2), 6.

McNeil, K., \& Kang, T. H.-K. (2013). Recycled Concrete Aggregates: A Review. International Journal of Concrete Structures and Materials, 7(1), 61-69. https://doi.org/10.1007/s40069-013-0032-5.

Osuji, S., \& Nwankwo, E. (2015). Marine Water Effect on Compressive Strength of Concrete: A Case Study of Escravos Area of Nigerian Delta. Nigerian Journal of Technology, 34(2), 240. https://doi.org/10.4314/njt.v34i2.4.

Šefflová, M., \& Pavlů, T. (2016). The Carbonation Depth of Fine Recycled Aggregate Concrete. Key Engineering Materials, 722, 228-232. https://doi.org/10.4028/www.scientific.net/KEM.722.228.

Wardeh, G., Ghorbel, E., \& Gomart, H. (2015). Mix Design and Properties of Recycled Aggregate Concretes: Applicability of Eurocode 2. International Journal of Concrete Structures and Materials, 9(1), 1-20. https://doi.org/10.1007/s40069-014-0087-y.

Wegian, F. M. (2010). Effect of seawater for mixing and curing on structural concrete. The IES Journal Part A: Civil \& Structural Engineering, 3(4), 235-243. https://doi.org/10.1080/19373260.2010.521048.

Wu, J., Diao, B., Ye, Y., \& Zheng, X. (2017). Chloride Diffusivity and Life Prediction of Cracked RC Beams Exposed to Different Wet-Dry Ratios and Exposure Duration. Advances in Materials Science and Engineering, 2017, 1-13. https://doi.org/10.1155/2017/5762048

Yue, P., Tan, Z., \& Guo, Z. (2013). Microstructure and Mechanical Properties of Recycled Aggregate Concrete in Seawater Environment. The Scientific World Journal, 2013, 1-7. https://doi.org/10.1155/2013/306714. 